\title{
Wpływ cyfryzacji infrastruktury informacyjnej na procesy badawcze w humanistyce. Wybrane aspekty zjawiska
}

\author{
Ewa Głowacka \\ Instytut Informacji Naukowej i Bibliologii, Uniwersytet Mikołaja Kopernika w Toruniu \\ Mirosław Górny \\ Instytut Językoznawstwa, Uniwersytet im. Adama Mickiewicza w Poznaniu \\ Małgorzata Kisilowska \\ Katedra Badań nad Bibliotekami i Innymi Instytucjami Kultury, \\ Wydziat Dziennikarstwa, Informacji i Bibliologii, Uniwersytet Warszawski \\ Zbigniew Osiński
}

Instytut Informacji Naukowej i Bibliotekoznawstwa, Uniwersytet Marii Curie - Skłodowskiej w Lublinie

\begin{abstract}
Abstrakt
Cel/Teza: Zbadanie przekształceń zachodzących w cyfrowej infrastrukturze informacyjnej humanistyki, opracowanie jej modelu oraz ustalenie widocznego już obecnie i przewidywalnego wpływu tych zmian i kształtującego się modelu na praktyki badawcze i publikacyjne badaczy; zaproponowanie metodyki przyszłych badań nad cyfrową infrastrukturą informacyjną.

Koncepcja/Metody badań: Pozyskanie i analiza danych dotyczących poszczególnych składników cyfrowej infrastruktury informacyjnej oraz danych o wykorzystywaniu tejże przez wybrane grupy humanistów. Wyniki i wnioski: Opracowano model cyfrowej infrastruktury informacyjnej humanistyki; wyróżniono parametry jej badania; wykazano związek pomiędzy wykorzystywaniem składników infrastruktury, a poziomem kompetencji informacyjnych i stanem świadomości informacyjnej; opisano aktualny stan wykorzystywania cyfrowej infrastruktury przez humanistów oraz opracowano mechanizmy jej potencjalnego wpływu na przyszłe praktyki badawcze humanistów.

Oryginalność/Wartość poznawcza: Opracowano oryginalny model cyfrowej infrastruktury informacyjnej oraz parametry do jej badania; wykazano potencjalne utrudnienia w takich badaniach oraz możliwy wpływ rozwoju infrastruktury na praktyki badawcze.
\end{abstract}

\section{Słowa kluczowe:}

Badania humanistyczne. Cyfrowa infrastruktura informacyjna. Kompetencje informacyjne. Świadomość informacyjna.

Otrzymany: 27 maja 2017. Zrecenzowany: 28 listopada 2017. Poprawiony: 30 listopada 2017.

Zaakceptowany: 28 grudnia 2017.

\section{Wstęp}

Pojęcie „infrastruktura informacyjna” weszło do naukowego obiegu w latach 90. XX w. Powstała wtedy koncepcja infrastruktury informacyjnej, ale jako konstruktu politycznego infrastruktura państwa i administracji (Report, 1994). Termin ten rozpowszechnił się za 
sprawą dokumentów programowych OECD, G-7, Unii Europejskiej i rządu Stanów Zjednoczonych, poświęconych zmianom cywilizacyjnym prowadzącym do kształtowania się społeczeństwa informacyjnego. W rzeczywistości naukowej o infrastrukturze informacyjnej zaczęto wspominać w kontekście rozwoju Internetu. Z definicji mających zastosowanie do opisywania tejże rzeczywistości warto przytoczyć tę, którą sformułował John P. Pironti (2006). Do infrastruktury informacyjnej zaliczył on wszystkich ludzi, procesy, procedury, narzędzia, urządzenia i technologie, które uczestniczą w procesie tworzenia, użytkowania, przekazywania, przechowywania i niszczenia informacji. Dla rozważań zaprezentowanych w niniejszej pracy istotna jest także definicja Claudio U. Ciborry i Ole Hansetha (1998, 305-327), z której wynika, że infrastruktura informacyjna może kształtować nie tylko procedury pracy i metody działania, lecz także sposoby postrzegania tych praktyk przez ludzi. Wpływa też na to, że pracownicy i obywatele traktują te praktyki jako „naturalne”, nadaje im walor niezbędności, konieczności. W tej definicji infrastruktura informacyjna jawi się jako czynnik wspierający akceptację i osobistą implementację określonych rozwiązań i praktyk organizacyjnych.

W realiach polskiej nauki można odnieść wrażenie, że definiowanie infrastruktury informacyjnej w początkowym okresie kształtowania się tego pojęcia opanowali głównie informatycy i ekonomiści. Michał Goliński (1997, 6-7) napisał, że jest ona techniczną i technologiczną częścią krajobrazu informacyjnego współczesnego społeczeństwa. Całość tych rozwiązań opiera się na osiągnięciach w obszarze informatyki, telekomunikacji i mediów elektronicznych. W jego koncepcji infrastruktura informacyjna jest pojęciem dosyć wąskim, obejmującym jedynie najnowsze rozwiązania - sferę cyfrową. Szerszą definicję, nieograniczającą się wyłącznie do współczesnych rozwiązań cyfrowych, kilka lat później podał Józef Lubacz $(2002,55)$. Uznał on, że infrastruktura informacyjna obejmuje oprócz techniki i technologii, także rozwiązania instytucjonalne, regulacje prawne i usługi świadczone z ich wykorzystaniem. Szeroką definicję stworzył także Józef Oleński (2006, 270-271). Ujął w niej kompleks instytucji, jednostek organizacyjnych, systemów, technologii oraz zasobów informacyjnych, z podziałem na infrastrukturę informacyjną społeczną, polityczną, gospodarczą, regionalną, państwową i globalną. Z kolei według Bolesława Szafrańskiego $(2006,11)$, infrastruktura informacyjna jest zbiorem procedur, modeli, systemów, zasobów informacyjnych oraz ludzkich, których zadaniem jest zgodne z prawem gromadzenie, przechowywanie, przetwarzanie i udostępnianie informacji w celu realizacji dowolnych zadań.

W początkach XXI w. pojawił się termin „cyberinfrastruktura” (Bowker et al., 2010). Obejmuje on sprzęt i oprogramowanie komputerowe, sieci informatyczne, zbiory danych, a także cyfrowe czujniki, narzędzia i usługi oraz odpowiednio przeszkolony personel. Kilka lat wcześniej Ole Hanseth (2002) słusznie zauważył, że rozwiązania informatyczne, tworzące współczesną infrastrukturę informacyjną, pod wieloma względami znacznie różnią się od tradycyjnych systemów informacyjnych. Co prawda nowa, cyfrowa infrastruktura rozwijana jest poprzez rozszerzanie, modyfikowanie i ulepszanie rozwiązań istniejących, ale ich digitalizacja i cyfryzacja stwarza zupełnie nowe możliwości w zakresie dostępności i potencjalnych możliwości wykorzystania. Na dodatek digitalizacja i cyfryzacja stwarzają samonapędzający się mechanizm generujący kolejne rozwiązania, których kształtu i znaczenia dziś nie możemy nawet przewidzieć, a z którymi niewątpliwie będziemy mieli do czynienia z powodu rosnącego tempa pojawiania się nowości. 
W nauce o informacji infrastruktura informacyjna mieści się w trzech innych pojęciach: „środowisko informacyjne”, „infosfera” i „przestrzeń informacyjna”. Przeglądu sposobów ich interpretowania dokonała Małgorzata Kisilowska (2011, 35-52). Uznała, że pojęcie środowisko informacyjne jest używane najczęściej intuicyjnie, ale można wyróżnić dwa sposoby jego definiowania. Pierwszy kładzie nacisk na sferę techniczną i wskazuje na zespół narzędzi i zasobów umożliwiających użytkownikom tworzenie własnych aranżacji przestrzeni informacyjnych. Drugie podejście wskazuje na istnienie zbioru osób, organizacji i systemów, w którym dochodzi do gromadzenia, przetwarzania i rozpowszechniania informacji. Jeżeli chodzi o pojęcie „infosfera”, to Kisilowska uznała, iż jest ono utożsamiane z cyfrowym światem informacji, z techniką umożliwiającą tworzenie rzeczywistości wirtualnej. W przypadku przestrzeni informacyjnej wykazała istnienie cech wspólnych dla różnych definicji. Zaliczyła do nich: wyraźnie zarysowane granice, które mają charakter indywidualny; istnienie centralnego obiektu w postaci aktywnego użytkownika lub elementu nieożywionego - źródła informacji, który decyduje o kształcie i jakości tejże przestrzeni oraz relacje człowieka z przestrzenią informacyjną, które zależą od jego wiedzy i kompetencji informacyjnych. Wskazała na istnienie wąskiej i szerokiej interpretacji tego pojęcia. W wąskim znaczeniu przestrzeń informacyjna jest zbiorem źródeł informacji wykorzystywanych przez poszczególne osoby lub zbiorem informacji generowanych przez jedno źródło. Szersza interpretacja zakłada istnienie środowiska pracy systemów informacyjnych i kształtowania się przestrzeni relacji z użytkownikami informacji. Kisilowska dostrzegła fakt, że trzy omawiane pojęcia używane są synonimicznie, z tym, że za najwłaściwsze dla nauki o informacji, ze względu na specyfikę badań, uznała pojęcie przestrzeni informacyjnej. Jednakże, bez względu na to, którego z tych pojęć używamy, to zawsze mamy na myśli także infrastrukturę informacyjną. Bowiem każde z nich obejmuje zbiory treści i ich nośniki.

\section{Cel i metodyka badań}

Przedstawiony przegląd definicji wykazuje, że rola infrastruktury informacyjnej w działalności informacyjnej i wiedzotwórczej, także w nauce, jest kluczowa. Co więcej, zdaje się rosnąć w związku z procesami cyfryzacji obejmującymi coraz większe obszary ludzkiej aktywności, także badawczej. Stąd też badania infrastruktury informacyjnej, zwłaszcza jej cyfrowej części, wydają się istotne dla zrozumienia procesów naukowych i zachodzących w nich zjawisk oraz pojawiających się tendencji. Wagę tych badań powiększa fakt, iż szybko rozrastające się środowisko informacyjne stwarza dla badaczy nie tylko wiele szans, lecz także zagrożeń. Ustalenie wpływu konkretnych rozwiązań infrastrukturalnych na wspomniane szanse i zagrożenia jest istotne dla sprawnego rozwoju nauki. Dlatego też autorzy niniejszego tekstu postawili sobie za cel zbadanie przekształceń zachodzących w cyfrowej infrastrukturze informacyjnej humanistyki, opracowanie jej modelu oraz ustalenie widocznego już obecnie i przewidywanego wpływu tych zmian i kształtującego się modelu na praktyki badawcze i publikacyjne badaczy. Celem pracy jest także zaproponowanie metodyki przyszłych badań nad cyfrową infrastrukturą informacyjną.

Podstawą badań było pozyskanie danych dotyczących poszczególnych składników cyfrowej infrastruktury informacyjnej oraz danych o wykorzystywaniu tejże infrastruktury przez humanistów. Pierwszą część zadania zrealizowano poprzez eksplorację Internetu. 
Druga część sprowadzała się do badań ankietowych przeprowadzonych w 2015 r. wśród historyków, językoznawców oraz biblio- i informatologów z ośrodków uniwersyteckich w Lublinie, w Poznaniu, w Toruniu i w Warszawie (w badaniach wzięły udział 62 osoby). Uznano, że uczelnie te, różniące się wielkością, pozycją w rankingach, a także położeniem geograficzno-kulturowym, utworzyły względnie reprezentatywną próbę. Z kolei wybrane dyscypliny nauk humanistycznych charakteryzuje stosunkowo duże uzależnienie od piśmiennictwa i znaczny potencjał oferowany badaczom przez Internet. Pytania zostały tak sformułowane, by dostarczyć danych na temat wykorzystywania w codziennej praktyce określonych składników infrastruktury, znajomości stanu cyfrowej infrastruktury, kompetencji do posługiwania się jej elementami oraz stanu świadomości w zakresie skali i zasobności tejże infrastruktury oraz możliwości, jakie stwarza (ankieta została opublikowana jako aneks do pracy: Górny i in., 2017). Respondenci odnosili się do gotowych wskaźników (pytania zamknięte) lub musieli podać własne informacje (pytania otwarte krótkiej odpowiedzi). Dodatkowo zebrano dane o stanie kont bibliotecznych humanistów na wybranych uczelniach za 2015 r., wychodząc z założenia, że część pracowników naukowych nie wykorzystuje bibliotecznego zasobu publikacji drukowanych, co oczywiście może wskazywać na wykorzystywanie zasobów cyfrowych. Eksploatowano także dane pochodzące z 2015 r. z serwera Biblioteki Głównej UMCS w Lublinie, pokazujące wykorzystywanie przez tamtejszych humanistów różnych składników infrastruktury, do których biblioteka zapewnia dostęp dzięki wykupionym licencjom. Zgromadzono też dane o praktykach polskich historyków, językoznawców oraz biblio- i informatologów w zakresie cytowań, pochodzące z kilkunastu czasopism (Annales UMCS Sectio F Historia, Białostockie Teki Historyczne, Bibliotheca Nostra, Czasy Nowożytne, Kwartalnik Historyczny, Pamiętnik Literacki, Przeglad Biblioteczny, Praktyka i Teoria Informacji Naukowej i Technicznej, Res Historica, Roczniki Biblioteczne, Toruńskie Studia Bibliologiczne, Zagadnienia Informacji Naukowej). Część danych pochodzi z publikacji z okresu przed gwałtownym rozwojem cyfrowej infrastruktury informacyjnej (1998-2000), a część z ostatnich kilku lat (2013-2015).

\section{Model cyfrowej infrastruktury informacyjnej humanistyki}

Eksploracja Internetu pozwoliła stworzyć model cyfrowej infrastruktury informacyjnej humanistyki. Według autorów artykułu składa się on z sześciu grup zasobów i narzędzi wyróżnionych ze względu na przydatność do poszczególnych etapów naukowej aktywności humanistów:

(1) Źródła informacji bibliograficznej:

a. międzynarodowe, wielodziedzinowe bazy bibliograficzne (Central European Journal of Social Sciences and Humanities, EBSCO Host, Scopus, Web of Science);

b. międzynarodowe, dziedzinowe bazy bibliograficzne (np. Bibliograficzna baza danych do historii Europy Środkowo-Wschodniej Herder Instytut, Slavic Humanities Index, VifaOst - Wirtualna Biblioteka Wschodnia);

c. cyfrowe wersje drukowanych bibliografii ogólnych (np. Bibliografia Narodowa Biblioteki Narodowej, Bibliografia Estreichera, Polska Bibliografia Literacka);

d. cyfrowe bibliografie dziedzinowe i specjalistyczne (np. ARTON - Polska Literatura Humanistyczna, Bibliograficzna Baza Danych do Historii Europy 
Środkowo-Wschodniej LitDok, Bibliografia Etnografii Polskiej, Bibliografia Historii Polskiej, Bibliografia Historii Kościoła, Bibliografia Historii Wielkopolski i Bibliografia Powstania Wielkopolskiego, Bibliografia Polskich Badań nad Antykiem i Tradycją Antyczną, iSybislaw - Bibliograficzna Baza Danych Światowego Językoznawstwa Slawistycznego, bibliografie specjalne Biblioteki Narodowej, bibliografie tematyczne Centralnej Biblioteki Wojskowej, Bibliographie de Civilisation Medievale, Bibliographie Internationale de l'Humanisme et de la Renaissance, Bibliography of British and Irish History i inne wydawnictwa Brepols , European Bibliography of Slavic and East European Studies , La Base d’Information Bibliographique en Patristique - tzw. Bibliografia Ojców Kościoła, Polska Bibliografia Literacka, Philosopher's Index, Retrospektywna Bibliografia Literackiej Zawartości Czasopism XIX i XX w. - bibliografia Bara);

e. bibliografia dorobku poszczególnych badaczy (Polska Bibliografia Naukowa, Nauka Polska - baza Ludzie Nauki, bibliografie dorobku pracowników poszczególnych uczelni, profile pracownicze - w dwóch ostatnich przypadkach dane dostępne są na stronach WWW uczelni);

f. międzynarodowe katalogi biblioteczne online (OPAC) obejmujące wiele bibliotek (np. DART - Europe, The European Library, WorldCat, The Karlsruhe Virtual Catalog);

g. polskie katalogi biblioteczne online (OPAC) obejmujące wiele bibliotek (Katalog Rozproszony Bibliotek Polskich KaRo, Narodowy Uniwersalny Katalog Centralny NUKAT);

h. katalogi online (OPAC) poszczególnych bibliotek (biblioteki tradycyjne - lista: http://www.ebib.pl/biblioteki, biblioteki cyfrowe - lista: http://fbc.pionier.net. $\mathrm{pl} /$ owoc/list-libs).

(2) Źródła wiedzy naukowej:

a. książki naukowe w formie e-booka dostępne w e-księgarniach, na stronach WWW wydawców, w repozytoriach (instytucjonalnych lub dziedzinowych) i bibliotekach cyfrowych;

b. artykuły naukowe dostępne w czasopismach elektronicznych oraz w czasopismach zdigitalizowanych i udostępnianych w bibliotekach cyfrowych;

c. prace naukowe nieformalnie umieszczane przez autorów w ogólnodostępnych repozytoriach typu Academia.edu, BookZZ, Research Gate i Zenodo lub na własnych stronach WWW;

d. pełnotekstowe bazy artykułów i książek naukowych (np. Biblioteka Wirtualnej Nauki, BazHum, Czytelnia Czasopism PAN, IBUK Libra, Central and Eastern European Online Library, ISTOR, Academic Search Complete, Cambridge Journals, De Gruyter Open, Oxford Journals, Wiley Online Library, Taylor \& Francis Online, ScienceDirect);

e. repozytoria prac naukowych: instytucjonalne (np. Repozytorium Uniwersytetu im. Adama Mickiewicza w Poznaniu AMUR, Repozytorium Uniwersytetu Łódzkiego RUŁ, Repozytorium Publikacji Naukowych Politechniki Śląskiej i Repozytorium Dolnośląskiej Szkoły Wyższej oPUB) i dziedzinowe (np. e-Lis, PhilSci Archive).

(3) Narzędzia do pozyskiwania i gromadzenia danych bibliograficznych oraz pełnych tekstów prac: 
a. internetowe wyszukiwarki ogólne (np. Bing, Google) i specjalistyczne (np. Google Scholar, Google Books, BASE, DRIVER, Microsoft Academic Search);

b. rejestry bibliotek cyfrowych i repozytoriów naukowych (np. OpenDOAR, Registry of Open Access Repositories);

c. agregatory danych o pracach naukowych (np. OAIster, OpenAIR, Agregator $\mathrm{CeON}$ );

d. międzynarodowe spisy czasopism (np. Ulrich's Periodical Directory, ERIH Plus);

e. międzynarodowe spisy czasopism open access (np. Directory of Open Access Journals, Open Academic Journals Index, JURN, Journals for Free, Electronic Journals Library);

f. polskie spisy czasopism (Arianta);

g. wewnętrzne mechanizmy wyszukiwawcze repozytoriów i bibliotek cyfrowych;

h. menedżery bibliografii (np. Citavi, EndNote, Mendeley, Pepers, RefWorks, Zotero).

(4) Cyfrowe zasoby źródeł do badań humanistycznych:

a. projekty digitalizacji dóbr kultury (np.: Brepolis, Europeana, Gallica, London Lives 1690 to 1800, Monumenta Germaniae Historica, Monasterium.net, Patrologia Latina Database, Patristica, Acta Sanctorum, e-Codices, Manuscripta Mediaevalia, Corpus Scriptorum Latinorum, Vatican Library, Znak);

b. kolekcje cyfrowe archiwów i bibliotek (np.: kolekcje cyfrowe archiwów państwowych w Poznaniu i Lublinie oraz w Archiwum Państwowym m. st. Warszawy, Narodowe Archiwum Cyfrowe, archiwa Ośrodka Karta, Cyfrowa Biblioteka Narodowa Polona, Cyfrowa Biblioteka Druków Ulotnych, Polonijna Biblioteka Cyfrowa, kolekcje innych bibliotek cyfrowych zrzeszonych w Federacji Bibliotek Cyfrowych, e-kolekcja polskich czasopism Biblioteki Uniwersyteckiej w Warszawie, Kolekcja Starych Druków Biblioteki Instytutu Historycznego Uniwersytetu Warszawskiego, kolekcja cyfrowa Zakładu Narodowego im. Ossolińskich, Wirtualna Biblioteka Literatury Polskiej);

c. zbiory źródeł i danych stworzone w trakcie realizacji projektów naukowych (np. Atlas Źródeł i Materiałów do Dziejów Dawnej Polski, Database of Medieval Nubian Texts, The Valley of the Shadow, Railroads and the Making of Modern America, Texas Slavery Project, Photogrammar, Abbreviationes Online).

(5) Narzędzia do poszukiwania i transkrypcji cyfrowych zasobów źródeł do badań:

a. wewnętrzne wyszukiwarki archiwów i bibliotek cyfrowych;

b. przeszukiwarki zasobów w bibliotekach cyfrowych (np. Carrot2);

c. wyszukiwarki zespołów i jednostek archiwalnych (Archives Portal Europe, Szukaj w Archiwach, ELA, IZA, SEZAM, PRADZIAD, ZoSIA);

d. specjalistyczne wortale informacyjne (np. European History Primary Sources);

e. serwisy do dzielenia się danymi badawczymi (np. FigShare, RepOD);

f. narzędzia do transkrypcji (np. Transcription for Paleographical and Editorial Notation, Wirtualne Laboratorium Transkrypcji).

(6) Narzędzia do nawiązywania kontaktów i wymiany informacji:

a. naukowe serwisy społecznościowe (np. MethodSpace, H-Net, Index Copernicus Scientist Panel, ResearcherID, Clio-online, ResearchGate, Academici);

b. blogi naukowe (np. Warsztat badacza, Pedagog, Wizualizacja Informacji, New Humanist, Humanist Life); 
c. serwisy humanistycznych towarzystw naukowych (np. The Humanist, British Humanist Association, The Alliance of Digital Humanities Organizations, The Association for Computers and the Humanities, The European Association for Digital Humanities, Polskie Towarzystwo Historyczne);

d. wyszukiwarki konferencji naukowych (np. BazaKonferencji, EduFrog, Konferencja.org, Nature Events Directory, All Conferences).

\section{Parametry badania cyfrowej infrastruktury informacyjnej humanistyki}

Prowadzenie badań nad cyfrową infrastrukturą informacyjną humanistyki i jej wpływem na praktyki badawcze wymaga przyjęcia zestawu parametrów charakteryzujących poszczególne jej elementy. Ważne jest przy tym przyjęcie określonego punktu widzenia, bowiem informatyk inaczej będzie opisywał infrastrukturę informacyjną, inaczej urzędnik administracji, a zupełnie inaczej naukowiec. Doświadczenia autorów nabyte w trakcie badania tejże infrastruktury pozwalają na zaproponowanie zbioru parametrów przydatnych z punktu widzenia humanistów. Pierwszy zestaw przydatny jest do badania wykorzystywania poszczególnych składników infrastruktury przez badaczy i składa się z trzech par: znany - nieznany; dostępny - niedostępny; przydatny - nieprzydatny.

Przede wszystkim badacz wykorzysta jedynie te składniki infrastruktury, które zna. Stopień znajomości zależy zaś od kompetencji i doświadczeń konkretnego naukowca. Rozległość nieznanej danemu humaniście części cyfrowej infrastruktury może być nawet znaczna i wynika z szybkiego rozwoju internetowych zasobów i narzędzi. Potencjalny wpływ konkretnego składnika infrastruktury na praktyki badawcze w oczywisty sposób zależy od stopnia, w jakim jest znany. Wpływ ten zależy także od faktycznej dostępności składnika infrastruktury dla danego badacza. Dostępność może być ograniczona przez kilka czynników. Część zasobów i narzędzi jest dostępna odpłatnie, a niekiedy nie może być zakupiona przez pojedynczego badacza, lecz jedynie przez organizację (np. licencje na dostęp do Scopus i Web of Science). Realną dostępność ograniczają też kompetencje informatyczne, informacyjne i językowe konkretnej osoby. Pod uwagę należy wziąć także ograniczenia prawne, w tym te wynikające z prawa autorskiego. Powodują one, że do niektórych cyfrowych prac i kolekcji dostęp jest możliwy jedynie z komputerów zlokalizowanych w instytucji przechowującej dane źródła czy wypożyczającej dane prace. Kolejne ograniczenie dostępności jest skutkiem tworzenia plików w formatach (np. DjVu), które utrudniają indeksowanie cyfrowych zasobów przez specjalistyczną wyszukiwarkę tekstów i materiałów dla badaczy - Google Scholar. Częściowo łagodzi ten problem fakt, że wiele materiałów zgromadzonych w archiwach i bibliotekach cyfrowych we wspomnianym formacie indeksuje wyszukiwarka ogólna Google, z tym, że są one ukryte, często na odległych miejscach, w setkach, a nawet w tysiącach pozycji wyników wyszukiwania. Równie istotnym czynnikiem ograniczającym dostępność jest wydawanie cyfrowych czasopism i prac zbiorowych w formie jednego pliku, co skutecznie utrudnia wyszukanie poszczególnych artykułów i rozdziałów przez wyszukiwarki.

Wykorzystywanie danego składnika cyfrowej infrastruktury zależy nie tylko od tego, czy jest on znany i dostępny, lecz także, czy postrzegany jest jako przydatny do wykonania określonego zadania. Poczucie przydatności opierać się musi na znajomości danego 
zasobu i narzędzia. Dopiero wtedy możliwe jest skuteczne zastosowanie takich kryteriów przydatności, jak: zasobność i funkcjonalność merytoryczna adekwatna do wykonywanego zadania, funkcjonalność techniczna pozwalająca na sprawne wykorzystanie, a także nakład czasu, środków i sił adekwatny do rezultatu. Przykładem nieprzydatności wynikającej z tego ostatniego kryterium jest La Base d'Information Bibliographique en Patristique, w której brak możliwości wyszukiwania według określonych kryteriów. Dostępne są jedynie pliki PDF do przeglądania. Nieprzydatność może wynikać także z niewielkiej kompletności danych. Na przykład, niewielka reprezentatywność w Scopus i Web of Science środkowo-europejskiej humanistyki powoduje, że dla większości tematów badawczych tejże są to nieprzydatne bazy. Podobny skutek wywołuje nierozwijanie niektórych zasobów (jak np. bazy ARTON), przez co z czasem stają się coraz bardziej niekompletne.

Inny zestaw parametrów zastosujemy do badania procesów rozwojowych i zmian w cyfrowej infrastrukturze informacyjnej. W takim przypadku pomiary powinny dotyczyć:

- liczby jednostek tworzących dany zasób, jego wielkości i zmian zachodzących w określonym czasie;

- technicznego pochodzenia danego zasobu - powstał poprzez digitalizację wersji drukowanej lub jest „cyfrowo urodzony”;

- sprawstwa powstania i rozwoju zasobu - np. redakcja czasopisma, pracownicy biblioteki cyfrowej, kierownictwo instytucji, aktywność samopublikacyjna badacza;

- formatu danych i materiałów - np. PDF, HTML, DjVu, JPG;

- formy prawnej udostępniania - np. open access, licencje Creative Commons, domena publiczna;

- funkcjonalności - np. baza bibliograficzna, spis czasopism, katalog książek, abstrakty, pełne teksty prac, wyszukiwarka, oprogramowanie, archiwum, biblioteka;

- tematyki - związek z dyscypliną naukową, z problemami badawczymi.

\section{Infrastruktura informacyjna a świadomość i kompetencje informacyjne}

Wykorzystanie cyfrowej infrastruktury informacyjnej zależne jest od tych samych czynników, od których zależy wykorzystywanie całej infrastruktury informacyjnej nauki, czyli od świadomości i kompetencji informacyjnych konkretnego badacza. Świadomość informacyjna definiowana jest jako orientacja jednostki lub grupy w zakresie funkcjonowania w świecie informacji połączona z ogólną wiedzą na ten temat. To także rozumienie natury mediów i uświadomienie zagrożeń wynikających z bezkrytycznego poruszania się w morzu informacji (Batorowska, 2009, 73). Z kolei kompetencje informacyjne to umiejętności wyszukiwania, oceniania, selekcjonowania, interpretowania i wykorzystywania informacji, a także znajomość ich źródeł oraz sprawne posługiwanie się odpowiednimi narzędziami (Lau, 2011, 13-20).

Współczesne realia uprawiania zawodu naukowca powodują, że na wykorzystywanie elementów cyfrowej infrastruktury informacyjnej, na zaklasyfikowanie ich do przydatnych lub nieprzydatnych wpływają czynniki, które zaliczamy do sfery świadomości informacyjnej:

- prestiż, popularność i ważność w oczach badacza tytułu danego czasopisma, wydawcy, autora, źródła, zasobu;

- opinia, jaką posiada on o poziomie merytorycznym autora, czasopisma i wydawnictwa; 
- oczekiwana łatwość dotarcia i skorzystania z danego zasobu i narzędzia;

- „uświadomiona konieczność” wynikająca z zasad oceny okresowej pracownika, opinii przełożonego, a także z działania „pod recenzenta”.

Również kompetencje informacyjne konkretnego badacza w sposób istotny warunkują jego możliwości wykorzystania określonych składników infrastruktury. Możemy wyliczyć kilka związanych z tym zjawisk:

- mnogość rozwiązań, inicjatyw, zasobów i narzędzi i towarzyszący temu niedostatek informacji na ich temat;

- bariery informatyczne - nie każdy format danych czy dokumentu jest równie łatwy w wyszukaniu i wykorzystaniu, specjalistyczne narzędzia i bazy danych wymagają dużej biegłości informatycznej;

- wyniki wyszukiwania dostarczane przez najbardziej popularne wyszukiwarki, Google i Google Scholar, nie są tożsame z całością zasobów internetowych. Prawdopodobnie popularność tych narzędzi wynika z przekonania, że dostarczane przez nie wyniki są satysfakcjonujące. U jego źródła tkwi niewątpliwie brak wiedzy o tym, że wyszukiwarki te nie radzą sobie z przeszukiwaniem sporej części zasobów naukowych, nie tylko płatnych i wymagających logowania się, to także problem formatów udostępniania materiałów i umieszczania wielu tekstów w jednym pliku;

- problemy z tworzeniem indywidualnych strategii informacyjno-wyszukiwawczych, od których zależy skuteczność każdego narzędzia wyszukiwawczego.

\section{Infrastruktura informacyjna w praktyce badawczej polskich humanistów}

Prowadzone przez autorów badania wykazały, że rozwój cyfrowej infrastruktury informacyjnej dopiero zaczyna wpływać na praktykę badawczą polskich humanistów. Co prawda, na poszczególnych wydziałach, które uwzględniono w analizie aktywności na kontach bibliotecznych, od 74 do 13\% kont było w 2015 r. nieaktywnych, ale inne dane nie pozwalają na przyjęcie założenia, że aż tak licznej grupie humanistów do działalności dydaktycznej i naukowej wystarczają zasoby cyfrowe dostępne w sieci i nie muszą wypożyczać książek. Jednym z dowodów jest analiza porównawcza cytowań w kilkunastu czasopismach humanistycznych. Przyjęto założenie, że radykalny wzrost liczby i dostępności prac naukowych w wersji cyfrowej powinien przełożyć się na zmiany w cytowaniach. Do analizy wybrano dwa okresy - umownie nazwany „przedcyfrowym”: 1998-2000 i tzw. cyfrowy 2013-2015. Liczba sprawdzonych artykułów w obu próbach wyniosła ok. 600. Uzyskane dane wskazują na to, że strategie cytowań humanistów na razie nie uległy istotnej zmianie, a skutki cyfryzacji zaczynają do nich dopiero docierać. Wyraźny wzrost liczby cytowań na jeden artykuł (u historyków oraz biblio- i informatologów) może być efektem poprawy dostępności informacji o publikacjach i systematycznej digitalizacji samych publikacji. Jednakże u historyków powoływanie się w przypisach na prace dostępne w Internecie nie jest jeszcze popularne - jedynie w 10\% badanych artykułów z okresu 2013-2015 występują przypisy internetowe, ale dotyczą głównie materiałów źródłowych, a nie prac naukowych. Nie jest wiadomo czy historycy celowo unikają ujawniania, że powołują się na materiały znalezione w Internecie, czy rzeczywiście rzadko do nich docierają i dlatego rzadko je cytują. To jest jedno z ograniczeń badań opartych na analizach bibliometrycznych i ankietach. Nie da 
się tego problemu rozwiązać pytając autora, czy celowo pomijał adresy WWW cytowanych prac, czy może z zasobów sieci nie korzystał. Skoro nie zna zasobów Internetu lub jest dla niego czymś wstydliwym czerpanie z sieci, to raczej nie przyzna się do tego i da wymijającą odpowiedź sugerującą, że w Internecie nie ma nic interesującego lub zasoby sieci nie są wiarygodne.

Przesłanką wskazującą na to, że problem sprowadza się raczej do rzadkiego korzystania przez historyków z zasobów sieciowych jest statystyka dostępu do różnych baz naukowych za pośrednictwem serwera HAN (umożliwia wejście do płatnych baz, na które BG UMCS ma licencje - zarówno przez numery IP komputerów UMCS, jak i zdalnie - po zalogowaniu na stronie głównej BG UMCS). Okazuje się, że w 2015 r. właściwie nie korzystano z takich baz jak: International Directory of Medievalists i International Medieval Bibliography. Co prawda statystyki wejść do baz wielodziedzinowych (Ebsco, Ebrary, eJournals, IBUK Libra, Science Direct, Scopus, WoS) prezentują się pozornie (bez przeliczenia na liczbę pracowników UMCS) nie najgorzej, to jednak nie ma możliwości określenia, ile z tych wejść przypada na humanistów. Gdyby nawet przyjąć, że humaniści korzystają z tych baz tak, jak przeciętny użytkownik, oznacza to częstotliwość jeden lub dwa razy w roku. Kolejnym dowodem na nikłe wykorzystywanie internetowych zasobów i narzędzi są dane o aktywności polskich humanistów w naukowych portalach społecznościowych i w blogosferze. Od kilku lat autorzy aktywność taką stwierdzają (przy okazji różnych badań) jedynie w przypadku poniżej $1 \%$ badaczy zarejestrowanych w bazie Ludzie Nauki. Na tym tle zdecydowanie wyróżnia się aktywność redakcji czasopism naukowych. Polscy historycy wprowadzili do sieci prawie sto czasopism, których przynajmniej jeden kompletny rocznik udostępniają na zasadach open access. Obok czasopism tradycyjnych, które, oprócz wydawania wersji drukowanej, założyły własne strony WWW i zamieszczają na nich pliki PDF z artykułami lub całymi numerami, pojawiły się także czasopisma w pełni cyfrowe, wydawane jako typowy serwis internetowy z artykułami w formacie HTML (np. Kultura $i$ Historia, Prace Naukowe Akademii im. Jana Długosza. Zeszyty Historyczne). Powstają też specjalne platformy czasopism bazujące na Open Journal Systems (np. Czytelnia Czasopism PAN, Platforma Annales Universitatis Paedagogicae Cracoviensis, Platforma Czasopism Uniwersytetu Papieskiego Jana Pawła II w Krakowie, Akademicka Platforma Czasopism UMK w Toruniu, i poznańska PRESSto), na których aktualnie dostępne są czasopisma humanistyczne.

Badania sondażowe przeprowadzone przez autorów wykazały istnienie jeszcze innych zjawisk związanych z wykorzystywaniem przez humanistów cyfrowej infrastruktury badawczej:

- większość nie zna specjalistycznych narzędzi do wyszukiwania i zarządzania informacją (poza Google Scholar i Google Books, katalogami OPAC bibliotek, serwisu FBC, katalogami i bibliografiami Biblioteki Narodowej oraz NUKAT), słabo orientuje się w stanie cyfrowej infrastruktury informacyjnej;

- większość nie korzysta z możliwości badawczych stwarzanych przez zasoby i narzędzia Internetu (w analizowanej grupie badania oparte na sieci prowadzą pojedyncze osoby);

- duża liczba nie ma pozytywnego stosunku do publikowania wyłącznie cyfrowego, zwłaszcza w formule open access (61\%). Wykazuje też nieufność wobec takich publikacji;

- duża liczba nie dzieli się wiedzą w sieci (53\%), nie recenzuje, nie nawiązuje tam współpracy;

- znacząca część inicjatyw zmierzających do dzielenia się wiedzą w Internecie jest niewykorzystywana na szerszą skalę z powodu błędów informatycznych i informacyjnych. 
Najprawdopodobniej źródłem tych zjawisk są niskie kompetencje i określona świadomość informacyjna badaczy, zwłaszcza starszej generacji. Potwierdzeniem tej konstatacji mogą być badania dotyczące wykorzystywania Internetu przez naukowców, przeprowadzone w Czechach. Wykazały one, że tamtejsi przedstawiciele nauk społecznych i humanistycznych, co prawda dostrzegają znaczenie Internetu dla nauki, lecz głównie odczuwają związane z tym ograniczenia i trudności typu: ryzyko plagiatów, problemy z krytyką naukową zasobów internetowych, brak szkoleń w zakresie wykorzystywania nowoczesnych technologii oraz brak właściwej polityki naukowej państwa (Stellner \& Vokoun, 2014). Podsumowując, należy wyraźnie podkreślić, że aktualnie istnieje bardzo duża rozbieżność pomiędzy naukowymi możliwościami stwarzanymi przez cyfrową infrastrukturę informacyjną, a wykorzystywaniem ich przez polskich humanistów.

\section{Mechanizmy wpływu infrastruktury informacyjnej na przyszłe praktyki badawcze $w$ humanistyce}

Upowszechnienie wśród badaczy wiedzy na temat stanu infrastruktury informacyjnej oraz możliwości i ograniczeń, jakie ona stwarza może (i powinno) prowadzić do zmiany niektórych praktyk badawczych. Reformy polskiej nauki przyczyniły się do wzrostu zainteresowania problematyką obiektywizacji oceniania jakości prac naukowych, a także aktywności naukowej badaczy i jednostek naukowych. W tym celu zaczęto wykorzystywać wskaźniki bibliometryczne oparte na danych o liczbie publikacji oraz cytowaniach. Jednakże, biorąc pod uwagę aktualny stan rozwoju infrastruktury informacyjnej humanistyki, wydaje się, że badania oceniające stan i prognozujące kierunki rozwoju przynajmniej tej dziedziny nauki, oparte na bibliometrii, zarówno te ukierunkowane na analizę cytowań, jak i te oparte na analizie liczby publikacji naukowych przyporządkowanej do określonych badaczy i specjalności naukowych, nie przyniosą wartościowych rezultatów, o ile nie zostaną w nich uwzględnione uwarunkowania wynikające ze stanu tej infrastruktury. Wykorzystywanie jedynie metod obliczeniowych typowych dla matematyki, informatyki, statystyki matematycznej czy ekonometrii nie pozwala bowiem ani na dostrzeżenie wpływu infrastruktury informacyjnej na zachowania badaczy, ani na poprawne zdiagnozowanie ich dorobku. Podkreślić należy, że podstawą metodyki badań opartej na analizie cytowań jest funkcjonujący w socjologii wiedzy naukowej tzw. paradygmat normatywny, będący uzasadnieniem dla badania rozkładów cytowań. Wśród głównych założeń tego paradygmatu Linda Smith (1981) wymieniła następujące:

- naukowiec przywołuje w bibliografii załącznikowej prace, które rzeczywiście wykorzystał;

- cytowanie odzwierciedla znaczenie i wpływ cytowanej pracy;

- cytuje się prace najlepsze z istniejących na dany temat.

Jeżeli weźmiemy pod uwagę motywacje, którymi w czasach presji publikacyjnej i „terroru" wskaźników bibliometrycznych kieruje się wielu badaczy, dobierając bibliografię oraz możliwości w tym zakresie stwarzane przez infrastrukturę informacyjną, to dojdziemy do wniosku, że paradygmat normatywny jest w dużym stopniu oparty na naiwnych założeniach. Dla nikogo znającego realia nauki nie jest tajemnicą, że w bibliografii umieszcza się nie tylko prace wykorzystane, uznane za przydatne i bardzo dobre, lecz także takie, które umieścić 
wypada ze względu na jej autora (przełożony, recenzent, kolega) lub chwilową popularność danej pozycji (nie wypada jej nie uwzględnić). Odrębnym problemem są tzw. samocytowania, które nie zawsze mają merytoryczne uzasadnienie. Cyfrowa infrastruktura informacyjna stwarza nowe możliwości w zakresie odchodzenia od założeń paradygmatu normatywnego. Dzięki internetowym wyszukiwarkom stosunkowo łatwo natrafić na dane bibliograficzne pracy, która w konkretnych badaniach powinna zostać wykorzystana. Jednakże nie jest to równoznaczne z dostępem do pełnego tekstu tej pracy. Może on bowiem być udostępniany jedynie za stosunkowo wysoką opłatą lub jedynie w sieci komputerowej konkretnej biblioteki czy uczelni. Może też istnieć wyłącznie w formie drukowanej niedostępnej w danym kraju. Rodzi to pokusę umieszczenia pracy w bibliografii, mimo że jej tekst nie był wykorzystany. Tendencję tę wspiera fakt, iż dzięki licznym otwartym repozytoriom naukowym i czasopismom open access możemy uzyskać dostęp do prac omawiających interesujący nas artykuł czy książkę. Możliwe jest włączenie tego opisu do tworzonego tekstu w sposób stwarzający wrażenie, że skorzystało się z pracy oryginalnej.

Wspomniany rozwój otwartych repozytoriów naukowych oraz czasopism open access generuje jeszcze jedną pokusę sprzeczną z zasadami paradygmatu normatywnego. Szybki i łatwy dostęp do zgromadzonych tam bardzo już licznych prac naukowych może zniechęcać do korzystania z tekstów trudno dostępnych. W takiej sytuacji bibliografia załącznikowa będzie zbiorem nie tyle prac wartościowych i przydatnych dla danego tematu badawczego, ile prac łatwo dostępnych. Rośnie też ryzyko rozpowszechniania się treści niezweryfikowanych naukowo, gdyż w repozytoriach nieinstytucjonalnych (np. Academia. edu) każdy może umieścić tekst przypominający pracę naukową. Poza tym dużą część upublicznionych tam prac stanowią wersje robocze, przed recenzjami, a więc mogące zawierać błędy i niedociągnięcia. Nie do końca można być pewnym także naukowej wartości niejednego internetowego czasopisma, stosującego co prawda otwarty dostęp dla czytelników, ale pobierającego opłaty od autorów. Czy właściciele takich czasopism oprą się pokusie zwiększania zysków za cenę liberalizacji zasad recenzowania? Rozwój zasobów open access powoduje, że szczególnie ważne stają się wiedza i kompetencje czytelnika, warunkujące sprawne ocenianie wartości znalezionych materiałów. Słuszne obawy rodzi łatwość plagiatowania prac udostępnionych w Internecie, ale równie łatwe jest wykrycie tego nadużycia (np. dzięki możliwościom Dupli Checker - https://www.duplichecker.com/). Jednakże wymogi wielu amerykańskich i europejskich uczelni oraz grantodawców, a także polityka Unii Europejskiej wywierają na tyle silną presję na badaczy, że mimo wspomnianych problemów, można być pewnym dalszego, szybkiego rozwoju zasobów prac naukowych dostępnych w Internecie na zasadach open access.

Istnienie licznych baz danych bibliograficznych oraz informatycznych narzędzi wyszukiwawczych i analitycznych skutkuje rozwojem badań ilościowych i tworzeniem na ich podstawie różnorodnych map i diagnoz nauki. Jednakże planując tego typu badania naukoznawcze i bibliometryczne należy uwzględnić fakt, że aktualny stan cyfrowej infrastruktury informacyjnej humanistyki stwarza poważne ryzyko popełnienia błędów na etapie gromadzenia danych do badań ilościowych opartych na metodach matematycznych. Dowodem niech będą badania (Osiński, 2014; 2015), które wykazały, że istniejących bibliograficznych baz danych i indeksów czasopism nie można uznać za w miarę kompletne i wiarygodne źródła informacji o stanie światowej historiografii i dorobku poszczególnych historyków, gdyż zawierają istotne luki i nieścisłości. Powszechnie wykorzystywane wyszukiwarki 
Google i Google Scholar, nie są zaś niezawodnymi dostawcami danych o dorobku z zakresu historiografii, co spowodowane jest błędami o charakterze informatycznym, popełnianymi przez redakcje czasopism, pracowników repozytoriów oraz przez samych autorów prac. Tak więc wszelkie diagnozy i mapowania nauki powinny być wolne od przekonania, że dzięki Internetowi i metodom ilościowym można je zrealizować szybko i obiektywnie.

Ważnym aspektem rozwoju cyfrowej infrastruktury informacyjnej humanistyki jest budowa bibliotek i archiwów cyfrowych, a także repozytoriów danych badawczych. Humaniści znajdą w tych miejscach duże zbiory źródeł i danych do badań, często dostępnych online bez żadnych ograniczeń. Skorzystanie z nich jest równie łatwe, jak z cyfrowych prac naukowych. W związku z tym możliwe jest pojawienie się tendencji do wybierania takich tematów badawczych, które można zrealizować dzięki źródłom i danym dostępnym online. W związku z tym może zaznaczyć się wpływ doboru zbiorów danych i materiałów przeznaczonych do digitalizacji na podejmowaną tematykę badań. Wpływ bibliotecznych i archiwalnych decydentów na wybór kolekcji i dokumentów do digitalizacji i udostępniania stanie się czynnikiem warunkującym tematykę, a nawet pośrednio i rezultaty badań oraz powstawania wiedzy. Ten sam problem wystąpi w przypadku aktywności tych badaczy, którzy udostępniają zbiory danych. Naukowiec bowiem może sądzić , że ma do czynienia z kompletem danych i źródeł, a de facto będzie miał do czynienia $\mathrm{z}$ ich selekcją dokonaną na podstawie sondowania największego zainteresowania potencjalnych użytkowników, chęcią zdygitalizowania i udostępniania danego zbioru. Istnieje też ryzyko dekontekstualizacji materiału, który oderwany od konkretnej kolekcji oraz od specyfiki wytwórcy, może zafałszowywać przekaz informacji, tworzyć realia niezgodne ze stanem faktycznym. Z drugiej strony, wiele kolekcji cyfrowych zawiera filmy, zdjęcia i nagrania audio, dzięki czemu te materiały mają szansę na, częstsze niż do tej pory, wykorzystanie w charakterze źródeł do badań. Na przeszkodzie intensywniejszemu wykorzystywaniu tego elementu infrastruktury informacyjnej stoi Ustawa o prawie autorskim i prawach pokrewnych, zgodnie z zapisami której część materiałów zdigitalizowanych w bibliotekach i archiwach cyfrowych, powstałych po 1939 r., udostępnianych jest jedynie na komputerach znajdujących się w danej instytucji, a więc nie ma do nich łatwej i szybkiej ścieżki dotarcia właściwej dla kolekcji dostępnych online. Rozwój technologiczny stwarza nadzieję na to, że coraz większa część źródeł do badań udostępniana będzie w formie standardowego skanu (pliku graficznego) i w dodatkowej formie tekstowej, opartej na odpowiednim schemacie XML. Każdy element treści może być wtedy opisany właściwym znacznikiem (tagiem), pozwalającym odpowiednim programom rozpoznać znaczenie treści przetwarzanych dokumentów i na tej podstawie tworzyć różnorodne zestawy danych. Dostrzec też można powszechne dążenie do tworzenia kolekcji z funkcją przeszukiwania pełnotekstowego oraz do umożliwiania robotom Google indeksowania zasobów bibliotek cyfrowych. Stworzy to nową jakość, jeżeli chodzi o wykorzystywanie infrastruktury informacyjnej przez humanistów. Należy jednak zwrócić uwagę na fakt, że część cyfrowych zasobów stworzona jest w sposób zniechęcający do korzystania - niewyraźne skany, brak wewnętrznych mechanizmów wyszukiwawczych i przeszukujących (przeszukiwanie pełnotekstowe), konieczność żmudnego przeglądania zdigitalizowanych czasopism, książek i dokumentów na zasadzie - strona po stronie, bardzo wolne ładowanie się stron i plików. Badacze mogą ograniczać swoją aktywność (wybór literatury, tematu badań i źródeł) do zasobów, które takich problemów nie stwarzają. 
Zapełnianie Internetu różnymi przejawami kulturotwórczej działalności człowieka (biblioteki, archiwa, muzea i media cyfrowe, media społecznościowe, blogosfera, kanały YouTube, serwisy naukowe i edukacyjne oraz inne podobne składniki tzw. cyberkultury) staje się motorem rozwoju humanistyki cyfrowej. Badacze uzyskują łatwy i tani dostęp do rezultatów umysłowej działalności człowieka, w tym do wielu narzędzi, także bezpłatnych, do wyszukiwania i automatycznego analizowania tychże rezultatów. Możliwe jest pojawienie się tendencji do preferowania tematyki o tyleż nowatorskiej, o ile przyciągającej ze względu na to, że duże ilości nowych oraz łatwo dostępnych źródeł i danych pojawiają się każdego dnia. W takich państwach jak Stany Zjednoczone, a także w Europie Zachodniej już dziś obserwuje się zmiany w aktywności wielu humanistów. Angażują się w tworzenie cyfrowych zasobów źródeł do badań (digitalizacja), różnych baz danych i systemów wyszukiwawczych. Przystąpili do wykorzystywania cyfrowych narzędzi do rozwijania nowej metodologii nauki i nowych zwyczajów publikacyjnych. Te najnowsze tendencje charakteryzują się łączeniem analiz jakościowych z ilościowymi, interdyscyplinarnością i multidyscyplinarnością, współpracą w zespołach, przyjęciem zasad open access i open source, publikowaniem prac multimedialnych, a także zainteresowaniem się cyberkulturą. Dostrzega się istnienie specyficznych, cyfrowych pól badawczych, do eksploracji których naukowcy wykorzystują technologie komputerowe dla znalezienia odpowiedzi na tradycyjne i nowatorskie pytania humanistyki. Cyfrowi humaniści poddają komputerowej eksploracji wielkie, zdigitalizowane korpusy tekstów, filmów, zdjęć itp. w celu poszukiwania nieodkrytych do tej pory regularności, trendów i prawidłowości. Tworzą mapy nauki, bazując na danych z różnorodnych baz bibliograficznych. Analizują słowne i obrazowe opisy rozwoju państw, miast, zabytków, instytucji, podróży, bitew itp., czyli dane jakościowe. Wzbogacają je komputerowo przetworzonymi danymi statystycznymi (ilościowymi). Następnie na tej podstawie generują naukowe syntezy w formie animacji lub cyfrowych opowieści. Badają przejawy internetowej cyberkultury oraz sieciowej aktywności ludzi. Wydaje się jednak, że te nowe metody i pola badawcze dostępne są jedynie niewielkiej grupie humanistów. W przypadku większości z nich problemem może być sprawne wykorzystywanie programów będących w stanie analizować duże zbiory danych, a także stosowanie programów do automatycznej analizy tekstów, obrazów, filmów, muzyki. Bowiem świadomość ich istnienia i umiejętność wykorzystywania jest niewielka, przynajmniej poza wąskim środowiskiem cyfrowych humanistów. Nieumiejętne posługiwanie się takimi narzędziami i zasobami, a także braki w opanowaniu odpowiednich metod badawczych, mogą przyczynić się do powstawania wiedzy niewiele mającej wspólnego z naukową. Barierę w wykorzystaniu cyfrowych zasobów przez innych badaczy niż tych zaliczających się do cyfrowych humanistów, stanową nie tylko niskie kompetencje informatyczne, lecz także nienadążanie rozwoju metodologii nauk humanistycznych za rozwojem cyfrowych narzędzi i zasobów.

Od połowy XX w. zauważyć można przemiany w medialnych i naukowych komunikatach związanych z problematyką naukową. Z liniowym tekstem zaczęły konkurować prezentacje infografik, zdjęć i filmów. Tendencje te nasiliły się wraz z rozwojem mediów cyfrowych, w tym Internetu, a w szczególności wraz z powstaniem cyfrowej humanistyki, która podjęła się badania cyfrowych wytworów człowieka. Pojawiła się nawet swoista moda na wizualizację wiedzy abstrakcyjnej, jaką w dużej mierze wytwarza większość dyscyplin humanistycznych - coraz więcej treści naukowych przybiera formę infografik, filmów i animacji. Charakterystyczne dla cyfrowych humanistów wykorzystywanie programów 
komputerowych do automatycznych analiz skutkuje pojawianiem się graficznych form prezentacji wyników tychże analiz. Twierdzi się, że skala produkcji danych i informacji zaczyna wymuszać na wszystkich, także humanistach, wizualizację zarówno na etapie analizy materiału badawczego, jaki i prezentowania efektów tychże analiz. Bowiem tradycyjna narracja liniowa i przekaz słowem pisanym nie są w stanie ogarnąć i opisać zjawisk kryjących się w wielkich zbiorach danych i różnorodnych bazach informacji (Radomski, 2016). Badacze problematyki wizualizacji przekonują, że ta forma przekazu dzięki syntezie, integracji i koncentracji informacji służy skondensowanemu przekazowi wiedzy, zwielokrotniając jej potencjał interpretacyjny w porównaniu z przekazem tekstowym. Zapewniają, że u podstaw tworzenia efektywnych wizualizacji stoją wyniki badań naukowych nad percepcją wzrokową i psychologią percepcji. Twierdzą, że wizualizacje bardziej efektywnie niż tekst wykorzystują nasz mózg, czynią złożone zbiory danych łatwiej zrozumiałymi, pozwalają na ich efektywną interpretację. Dzięki prezentowaniu informacji w atrakcyjnej i innowacyjnej formie przyciągają uwagę, podtrzymują zaangażowanie odbiorcy, pozwalają mu zauważyć coś, czego inaczej nie dostrzegłby i ułatwiają zapamiętywanie informacji (Carswell \& Wickens, 1987; Chen, 2006; Tufte, 2001; Ware, 2004). Biorąc pod uwagę rosnącą popularność graficznych form przekazu, a także fakt, że w społeczeństwie informacyjnym i gospodarce opartej na wiedzy znaczna część najnowszej „produkcji naukowej” powinna trafiać nie tylko do innych badaczy, lecz także do przedstawicieli wielu spośród pozostałych grup zawodowych, oczekiwać można, iż coraz większa grupa naukowców będzie decydowała się na prezentowanie wyników badań w formach graficznych.

Moda na posiadanie kont w serwisach społecznościowych i na prowadzenie blogów zapewnia rozwój nieformalnych dyskusji naukowych w Internecie. Powstały nawet specjalistyczne, naukowe serwisy społecznościowe (np. Index Copernicus Scientist Panel, MethodSpace, ResearcherID, ResearchGate). Ułatwiają one zdobywanie informacji o konferencjach, grantach, stażach, nowościach publikacyjnych, także nawiązywanie kontaktów. Jednakże wykorzystanie tych możliwości zależy wyłącznie od postawy samych badaczy. Niestety, jak przekonuje analiza aktywności polskich humanistów (Iwańska-Cieślik, 2016 a; 2016 b; Osiński, 2010), ich obecność jest tam stosunkowo niska. Biorąc pod uwagę przydatność wymienionych powyżej zasobów i narzędzi oraz względną łatwość ich wykorzystania, można podejrzewać, że wśród dużej grupy polskich humanistów istnieją silne bariery mentalne i kompetencyjne uniemożliwiające uczestniczenie w internetowej komunikacji naukowej. Jednakże należy podkreślić, iż możliwości współpracy przez Internet posiadają ogromną zaletę - przełamują bariery czasowo-przestrzenne. W związku z tym pojawiają się inicjatywy polegające na współtworzeniu projektów naukowych online (np. praca zbiorowa Writing History in the Digital Age, która powstała w nietypowy sposób, jako efekt oddolnej współpracy grupy autorów prowadzonej w Internecie: formę cyfrową miała zarówno współpraca - kontakty w Internecie - jak też jej efekt, czyli sama książka). Nieobecność badacza w świecie cyfrowym staje się takim samym czynnikiem ograniczającym jak nieznajomość języka angielskiego czy niski poziom kompetencji informatycznych. Internet stał się kluczowym obszarem pośredniczenia w komunikacji naukowej, więc nieobecni sami wykluczają się z tej komunikacji. 


\section{Zakończenie}

Na zakończenie należy podkreślić, że stosunkowo szybki i wszechstronny rozwój cyfrowej infrastruktury informacyjnej humanistyki stwarza duże możliwości w zakresie badania tempa, kierunków, prawidłowości i skutków tego procesu. Autorzy zaproponowali informatologiczną metodykę takich badań, na którą składa się model tej infrastruktury uwzględniający realia humanistyki, wskazujący na to, co należy badać. Następnie zaproponowali dwie grupy parametrów pozwalających w miarę precyzyjnie badać poszczególne składniki infrastruktury. Wskazali też na potencjalne błędy, które mogą zostać popełnione w trakcie takich badań. A także wykazali, że cyfrowa infrastruktura informacyjna może w określony sposób kształtować przyszłe praktyki badawcze i publikacyjne humanistów.

\section{Bibliografia}

Batorowska, H. (2009). Kultura informacyjna w perspektywie zmian w edukacji. Warszawa: Wydaw. SBP.

Bliźniuk, G., Szafrański, B. (2006). Interoperacyjność i bezpieczeństwo systemów informatycznych administracji publicznej. Katowice: Wydaw. PTI.

Bowker, G.C., Baker, K., Millerand, F., Ribes D., (2010). Toward Information Infrastructure Studies: Ways of Knowing in a Networked Environment. In: J. Hunsinger, L. Klastrup \& M. Allen, (eds.). International Handbook of Internet Research (97-117). Dordrecht: Springer Science+Business Media.

Carswell, M., Wickens, C. D. (1978). Information Integration and the Object Display: An Interaction of Task Demands and Display Superiority. Ergonomics, 30(3), 511-527.

Chen, Ch. (2006). Information Visualization: Beyond the Horizon. London: Springer-Verlag.

Ciborra, C.U., Hanseth O. (1998). From Tools to Gestell. Agendas for Managing Information Infrastructures. Information Technology E People. Special Issue on Heidegger and Information Technology, 11(4), 305-327.

Goliński, M. (1997). Poziom rozwoju infrastruktury informacyjnej społeczeństwa. Próba pomiaru. Warszawa: Akademicka Oficyna Wydawnicza PLJ.

Górny, M., Głowacka, E., Kisilowska, M., Osiński, Z. (2017). Mechanisms of the Formation and Evolution of Personal Information Spaces in the Humanities. Poznań: Wydaw. Rys.

Hanseth, O. (2002). From Systems and Tools to Networks and Infrastructures - From Design to Cultivation. Towards a Theory of ICT Solutions and Its Design Methodology Implications, [online] [15.06.2017], http://heim.ifi.uio.no/ oleha/Publications/ib_ISR_3rd_resubm2.html

Iwańska-Cieślik, B. (2016 a). Informacja o nowych publikacjach polskich bibliologów i informatologów w przestrzeni sieciowej (część I). Toruńskie Studia Bibliologiczne, 1(16), 211-238.

Iwańska-Cieślik, B. (2016 b). Informacja o nowych publikacjach polskich bibliologów i informatologów w przestrzeni sieciowej (część II). Toruńskie Studia Bibliologiczne, 2(17), 179-200.

Kisilowska, M. (2011). Przestrzeń informacyjna jako termin informatologiczny. Zagadnienia Informacji Naukowej, 2, 35-52.

Lau, J. (2011). Kompetencje informacyjne w procesie uczenia się przez całe życie. Wytyczne [online]. Stowarzyszenie Bibliotekarzy Polskich, [21.12.2017], https://www.ifla.org/files/assets/information-literacy/publications/ifla-guidelines-pl.pdf

Lubacz, J. (2002). Development of Information Infrastructure. In: W. Cellary (ed.). Human. Development Report. Poland and the Global Information Society. Warsaw: United Nations Development Program.

Oleński, J. (2006). Infrastruktura informacyjna państwa w globalnej gospodarce. Warszawa: Wydaw. UW. 
Osiński, Z. (2010). Nauka 2.0 w środowisku historyków najnowszych dziejów Polski. Praktyka i Teoria Informacji Naukowej $i$ Technicznej, 4, 25-31.

Osiński, Z. (2014). Europejskie czasopisma historyczne w bazach Scopus i Web of Science w kontekście oceny dorobku naukowego historyków w Polsce. Zagadnienia Informacji Naukowej, 52(2), 47-91.

Osiński, Z. (2015). Open access w środkowoeuropejskiej historiografii - perspektywa informatologiczna. Zagadnienia Informacji Naukowej, 53(2), 31-64.

Pironti, J.P., (2006). Key Elements of a Threat and Vulnerability Management Program [online]. ISACA, [21.12.2017], http://iparchitects.com/wp-content/uploads/2016/07/Key-Elements-of-a-Threatand-Vulnerability-Management-Program-ISACA-Member-Journal-May-2006.pdf

Radomski, A. (2016). Wizualne analizy, wizualne narracje. W: R. Bomba, A. Radomski, E. Solska (red.). Humanistyka cyfrowa. Badanie tekstów, obrazów i dźwięku (147-158). Lublin: Wydaw. E-Naukowiec.

Report (1994). Report on Europe and the Global Information Society: Recommendations of the High-level Group on the Information Society to the Corfu European Council. Bulletin of the European Union [online], Suppl. 2, [15.06.2017], http://aei.pitt.edu/1199/

Smith, L. C. (1981). Citation Analysis. Library Quarterly, 30(1), 83-106.

Stellner, F., Vokoun, M. (2014). Internet, Social Sciences and Humanities. Human Affairs, 24, 492-510. Tufte, E. R. (2001). The Visual Display of Quantitative Information. Cheshire, CT: Graphics Press. Ware, C. (2004). Information Visualization: Perception for Design. San Francisco, Morgan Kaufman.

\title{
Impact of Information Infrastructure Digitization on Research Processes in the Humanities. Selected Aspects of the Phenomenon
}

\begin{abstract}
Purpose/Thesis: Exploration of changes in the digital information infrastructure for the humanities; developing the model of this infrastructure, and describing both visible and expected impact of the model and the infrastructure itself on research and publishing behavior of the scholars; suggesting methods for future studies on digital information infrastructure.

Approach/Methods: Collection and analysis of data concerning selected elements of the digital information infrastructure and data on its usage by selected groups of the humanities' scholars.

Results and conclusions: The model of the digital information infrastructure for the humanities was developed; the parameters for exploring this infrastructure were defined; the relationship conjoining the infrastructure usage, the level of information literacy and the state of information awareness was proved to exist; the current usage of digital infrastructure by the humanities scholars was described, and the mechanisms of the infrastructure potential impact on research practices of the humanists were discovered.

Originality/Value: The original model of digital information infrastructure and parameters for the study of this infrastructure were developed; the potential obstacles for such research and the possible impact of the infrastructure development on research practices were identified.
\end{abstract}

\section{Keywords}

Digital information infrastructure. Humanities' research. Information awareness. Information literacy.

Dr hab. EWA GŁOWACKA - profesor Uniwersytetu Mikołaja Kopernika w Toruniu i dyrektor Instytutu Informacji Naukowej i Bibliologii UMK. Jej zainteresowania naukowe skupiają się wokót metodologii oceny 
jakości zasobów i ustug biblioteczno-informacyjnych, zarzadzania jakościq i wiedza. Wybrane publikacje: E. Gtowacka, M. Górny, M. Kisilowska, Z. Osiński (2015). Model indywidualnej przestrzeni informacyjnej w procesie badawczym - wstępne założenia, Zagadnienia Informacji Naukowej, 53(2),18-30; E. Głowacka (2016). Badania wykorzystania e-booków w bibliotekach: obszary, metody, problemy. W: M. Góralska, A. Wandel (red.), Metody i narzędzia badań piśmiennictwa cyfrowego i jego użytkowników (151-161). Wrocław: Wydaw. UWr; E. Gtowacka (2016). Propozycja modelu badań funkcjonalności serwisów www bibliotek cyfrowych opartego na zasadach architektury informacji. Biblioteka Nostra, 2(44), 23-32; E. Gtowacka (2016). Polskie repozytoria instytucjonalne jako miejsce dla otwartych zasobów naukowych i edukacyjnych. Zagadnienia Informacji Naukowej 55(1), 44-54.

Kontakt $z$ autorka:

egt@umk.pl

Instytut Informacji Naukowej i Bibliologii

Uniwersytet Mikotaja Kopernika w Toruniu

ul. Wtadystawa Bojarskiego 1

87-100 Toruń

Dr hab. MIROSŁAW GÓRNY - profesor UAM, kierownik Zakładu Systemów Informacyjnych w Instytucie Językoznawstwa UAM. Wybrane publikacje: M. Górny (2009). From the Old-Fashioned Library to the Public Library: Changes in the Cultural Functions of Polish Academic Libraries. In: W. Graves III et al., Advances in Library Administration and Organization (109-122). Emerald. Bingley 2009, vol. 27; M. Górny, P. Wierzchoń (2010). Polish Digital Libraries as a Philologists' Tools. Poznań; M. Górny, J. Mazurek (2012). Key Users of Polish Digital Libraries. The Electronic Library, 30(4), 543-556; M. Górny, J. Catlow, J. Mazurek (2015). Evaluating Polish Digital Libraries from the Perspective of Non-Academic Users. The Electronic Library, 33(4), 714-729.

\author{
Kontakt $z$ autorem: \\ mgorny@amu.edu.pl \\ Instytut Językoznawstwa \\ Uniwersytet im. Adama Mickiewicza w Poznaniu \\ Collegium Novum \\ al. Niepodlegtości 4 \\ 61-874 Poznań
}

Drhab. MAŁGORZATA KISILOWSKA - adiunkt na Wydziale Dziennikarstwa, Informacji i Bibliologii UW, zajmuje się zagadnieniami kulturowej funkcji bibliotek i informacji, a także kompetencji informacyjnych. Wybrane publikacje: M. Kisilowska (2016). Kultura informacji. Warszawa: Wydaw. SBP; M. Kisilowska, M. Paul, M. Zajac (2016). Jak czytaja Polacy? Warszawa: Centrum Cyfrowe Projekt: Polska; M. Kisilowska, J. Jasiewicz, A. Mierzecka (2016). Relativity is the Key: The Family of Digital Competencies' Catalogues and Their Potential Applications. In: S. Kurbanoğlu et al. (eds.) Information Literacy: Key to an Inclusive Society. Communications in Computer and Information Science Series, vol. 676 (294-303). Springer International Publishing AG.

Kontakt $z$ autorka:

mdkisilo@uw.edu.pl

Katedra Badań nad Bibliotekami i Innymi Instytucjami Kultury

Wydziat Dziennikarstwa, Informacji i Bibliologii

Uniwersytet Warszawski

ul. Nowy Świat 69

00-927 Warszawa

Dr hab. ZBIGNIEW OSIŃSKI - profesor w Instytucie Informacji Naukowej i Bibliotekoznawstwa UMCS w Lublinie; specjalności: informatologia, historia najnowsza Polski, metodyka i jakość ksztatcenia. Najnowsze publikacje: Z. Osiński (2016). Zasoby internetu jako podręcznik akademicki - studium przypadku przedmiotu organizacja i zarzadzanie informacja. e-Mentor, 3, 35-45; Z. Osiński (2016). Dyskusje o polskiej 
Akademii w odbiorze sceptycznego, cyfrowego humanisty i dydaktyka. Kronos. Metafizyka. Kultura. Religia, 3, 54-70; M. Górny, E. Gtowacka, Z. Osiński, M. Kisilowska (2016). The Importance of the Study of Individual Information Space for Library Science. In: Proceedings of the 2016 International Conference on Library and Information Science (LIS 2016) Kyoto, Japan 12-14.07.2016, (86-103). International Business Academics Consortium, Taipei; Z. Osiński (2016). Historia Polski w czasopismach indeksowanych w bazie Scopus. W: E. Gtowacka, M. Jarocki, N. Pamuła-Cieślak (red.), Wspótczesne oblicza komunikacji i informacji (191-212). Przestrzeń informacyjna nauki. Toruń: Wydaw. UMK.

Kontakt $z$ autorem:

zbigniew.osinski@gmail.com

Instytut Informacji Naukowej i Bibliotekoznawstwa

Uniwersytet Marii Curie-Skłodowskiej w Lublinie

pl. Marii Curie-Sktodowskiej 4

20-031 Lublin 